\title{
PENGARUH MODEL INSTRUKSIONAL KOOPERATIF TIPE CORE TERHADAP KEMAMPUAN REPRESENTASI MATEMATIS SISWA
}

\author{
Url Jurnal: https://uia.e-journal.id/akademika/article/1229 \\ DOI : https://doi.org/10.34005/akademika.v10i01. 1229
}

\author{
Submitted: 2021-02-10 Reviewed: 2021-05-09 Published: 2021-05-30 \\ Hendri Eka Jaya Putra \\ Universitas Pelita Harapan \\ hendriakajp1@gmail.com \\ Hendar Ahmad Wibisono \\ Universitas Negeri Jakarta \\ ahmad_hendar@yahoo.com
}

\begin{abstract}
The low learning outcomes of mathematics at junior high school level students are due to the low ability of students to use and assess the relationship between mathematics topics and organize the information obtained. One of the learning models with the discussion method that encourages students to use and assess the relationship between mathematical topics and organize the information obtained is the cooperative CORE (Connecting, Organizing, Reflecting, and Extending) learning model. The purpose of this study was to analyze the improvement of students' mathematical representation abilities through CORE models and analyzing differences in mathematical representation abilities between students using a cooperative CORE model with students using the learning method with the scientific approach, as well as to see student responses to the cooperative learning model type CORE. The method used is the Quasi Experimental Design method with type Non equivalent Control Group Design, with a population of all class VIII students of Al Ihsan Legenda Bekasi Junior High School for the 2019/2020 school year. The sampling technique used purposive sampling. The instruments used were questionnaire sheets and essay tests in accordance with the indicators of mathematical representation in the Functions. The results showed that there were differences in mathematical representation abilities between students who used the cooperative CORE model by using the learning method with a scientific approach, as well as student responses after using the CORE cooperative, make students more active and make it easier for students to learn the material and can improve student learning outcomes.
\end{abstract}

Keywords: cooperative learning, CORE, mathematical representation ability, mathematics learning.

Abstrak: Minimnya resulting pada evaluasi pembelajaran matematika pada siswa tingkat SMP
disebabkan masih lemahnya kemampuan siswa dalam mengaitkan keterkaitan antar beberapa
pembahasan matematika dan mengorganisasikan informasi yang diperoleh. Satu diantara banyaknya
model instruksional dengan cara diskusi yang lebih merangsang siswa dalam memanfaatkan dan
mengaitkan keterkaitan antar pembahasan matematika dan mengorganisasikan informasi yang diperoleh
adalah kegiatan instruksional kooperatif tipe CORE (Connecting, Organizing, Reflecting, and Extending).
Adapun maksud dilaksanakan riset ini adalah untuk menganalisis peningkatan kemampuan representasi
matematis siswa melalui model kooperatif tipe CORE dan menganalisis perbedaan kemampuan
representasi matematis yang terjadi antar siswa dengan penerapan model kooperatif tipe CORE
dibandingkan dengan siswa yang diimplementasikan metode pembelajaran dengan pendekatan 179 | Akademika | Vol 10 | No. 1 | 2021 
scientific, serta untuk melihat respons siswa terhadap model pembelajaran kooperatif tipe CORE. Metode yang digunakan adalah metode Quasi Experimental Design tipe Non equivalent Control Group Design, dengan populasi seluruh siswa kelas VIII SMPIT AI Ihsan Legenda Kota Bekasi tahun ajaran 2019/2020. Cara yang dilakukan dalam mengambil sampel penelitian dengan purposive sampling. Jenis instrumen penelitian yang dikembangkan adalah lembar angket dan test essay sesuai dengan indikator representasi matematis pada materi Fungsi. Dari Hasil penelitian terdapat signifikansi kemampuan representasi matematis antara siswa yang menggunakan model kooperatif tipe CORE dibandingkan metode pembelajaran dengan pendekatan saintifik, serta respons siswa selesai dilakukan penelitian dengan model pembelajaran CORE, ternyata berhasil merangsang siswa aktif dalam mempelajari materi dan juga berhasil dalam meningkatkan hasil belajar siswa.

Kata Kunci: pembelajaran kooperatif, CORE, kemampuan representasi matematis, pembelajaran matematika

\section{PENDAHULUAN}

Salah satu langkah yang diterapkan pemerintah demi meningkatnya mutu dan kualitas seluruh aspek pendidikan lbu Pertiwi pada tahun 2021 adalah menerapkan evaluasi berbasis Asesmen Kompetensi Minimum (AKM) yang diantara kempuan yang sudah semestinya dikuasai adalah kemampuan numerik-matematis. Bukan tanpa alasan tentu mengapa kemampuan matematis harus dikuasai oleh siswa dalam aktivitas keseharian seperti pada kehidupan keluarga, kegiatan sekolah, hingga kehidupan bermasyarakat. Instructional goals yang diharapkan matematika yang dirumuskan oleh NCTM (National Council of Teacher of Mathematics) (NCTM (National Council of Teachers of Mathematics), 2000) adalah untuk mengembangkan kemampuan antara lain: (1) kemampuan siswa dalam memecahkan berbagai jenis problematika (problem solving), (2) kemampuan siswa dalam melakukan percakapan (communication), (3) kemampuan siswa dalam membangun koneksi (connection), (4) kemampuan siswa dalam melakukan penalaran (reasoning), dan (5) kemampuan siswa dalam merepresentasikan segala sesuatu yang berkaitan dengan matematis (representation).

Diantara beberapa kemampuan yang sudah semestinya terinternalisasi oleh siswa untuk menunjang kegiatan instruksional matematika berbasis AKM adalah abilitas siswa dalam melakukan representasi matematis, representasi matematis adalah kemampuan siswa dalam memecahkan masalah yang dtemukan dalam pembelajaran matematika. Menurut Rose Mary et al., (2018) dalam Facilitator's Guidebook for Use of Mathmetics Situation in Professional Leaning menyebutkan bahwa representasi memainkan peran utama dalam cara siswa memahami konsep dan definisi Rose Mary et al., (2018). Oleh karenanya setiap kegiatan instruksional matematika, kemampuan siswa dalam menyampaikan gagasan maupun ide yang bersifat matematis adalah sebuah abilitas siswa yang sudah selayaknya dikuasi dalam kegiatan pembelajaran.

Era pembelajaran 4.0 menuju era 5.0 pendidikan tidak terlepas dari kaidah dasar yang sudah dirumuskan dalam Sistem Pendidikan Nasional nomor. 20 tahun 2003 dengan sangat gamblang disebutkan bahwa nilai intrinsik dan ekstrinsik yang terkadung dalam pendidikan seharusnya dapat diterapkan dalam kehidupan nyata, hal ini seperti yang dikatakan oleh Wibisono et al., (2020) dalam jurnal Prespektif Ilmu Pendidikan 
bahwa pembelajaran yang bermakna tidak pada satu titik kemampuan kognitif saja, namun bagaimana perpaduan aspek kognitif, afektif, dan psikomotorik dapat terpadu dalam sebuah pembelajaran yang bermakna.

Menurut penelitian yang dilakukan menunjukan bahwa hasil PISA (Program for International Student Asesment) Jaya Putra et al.,(2020) masih berada pada angka 389 jauh dibawah rata-rata OCED (Economic Development Cooperation Organization) dengan angka rata-rata 489.

Data observasi yang peneliti lakukan di SMPIT AI Ihsan Legenda Kota Bekasi, pada kelas VIII, diperoleh bahwa dalam pembelajaran matematika siswa terlihat hanya sedikit yang menunjukan sikap antusias tentu hal ini dapat disimpulkan karena hampir sebagian besar siswa yang mulai mengantuk, tidak adanya interaksi dua arah ketika proses pembelajaran matematika berlangsung, serta kurangnya peran aktif siswa dalam mengemukakan gagasan yang menarik mengenai materi yang disampaikan di kelas. Hal ini berakibat ketika siswa dihadapkan dengan suatu permasalahan, sebagian besar siswa belum memahami dan menerapkan permasalahan matematis, yang tentunya akan berdampak pada kemampuan repsesentasi siswa yang kurang optimal.

Data awal yang berhasil didapatkan dari kegiatan wawancara terhadap guru matematika di SMPIT Al Ihsan Legenda Kota Bekasi bahwa ternyata abilitas representasi matematis siswa dapat dikatakan pada tingkatan bawah. Hal ini didapatkan empirik dari hasil nilai Ujian Nasional (UN) matematika di SMPIT Al Ihsan Legenda Kota Bekasi pada tahun ajaran 2019/2020 ternyata 30\% siswa diantaranya masih mendapat nilai kurang dari 70 . Dari hasil ujian disimpulkan dalam kegiatan pembelajaran yang dilaksanakan masih belum mencapai rata-rata yang sudah diharapkan sebelumnya. Fakta tersebut diperkuat dari data hasil ulangan harian matematika kelas VIII tahun ajaran 2019/2020 pada materi pokok bahasan Fungsi. Hasilnya menunjukan nilai rata-rata siswa adalah 70,02 dengan $43 \%$ siswa di kelasnya masih kurang dari ketuntasan belajar yang ditetapkan yaitu 75 . Tentu saja ini mengindikasikan bahwa penguasaan siswa terhadap konsep matematika pada pembahasan fungsi masih kurang.

Faktor-faktor penyebabnya karena dalam kegiatan pembelajaran terutama pada pokok bahasan fungsi, banyak siswa hanya terfokus ke dalam suatu rumus tertentu, sehingga siswa sulit ketika berusaha memahami pembahasan yang telah dipelajari sehingga mengakibatkan hasil belajar siswa kurang dan penguasaan materi lemah bahkan sering keliru dalam pemecahan masalah, siswa juga cenderung cepat lupa serta hanya terfokus pada contoh soal yang berakibat ketika soalnya diganti dengan variasi lain membuat banyak siswa yang kebingungan untuk dapat menyelesaikan soal yang telah dipersiapkan untuk diselesaikan oleh guru. Siswa kesulitan dalam menerapkan ilmu atau materi aspek matematika dalam kegiatan keseharian, terlebih lagi siswa yang mengalami kesukaran dalam menyelesaikan soal matematika berbasis soal cerita masih terbilang tinggi. Semua ini disebabkan karena sulitnya memahami konsep serta prinsip matematika yang bersifat abstrak. Ditambah lagi masih berkembangnya paradigma lama bahwa matematika itu sulit oleh kebanyakan siswa. Selain itu, belum diterapkannya kegiatan instruksional yang menggairahan dan merangsang antusiasme belajar siswa matematika sehingga diharapkan tumbuhnya nilai bahwa tenyata matematika itu menyenangkan. 
Dikutip dari (M. Pd, 2016) dalam Akademika Jurnal Teknologi Pendidikan bahwa sering kali kita menyadari bahwa kemampuan siswa dalam memecahkan masalah kerap kali diabaikan oleh guru, tentu saja ini memiliki implikasi yang membuat siswa mengalami kesulitan dalam memecahkan beberapa permasalahan dasar yang kerap kali dijumpai dalam kesehariannya mereka. Akibatnya banyak siswa yang mudah putus asa ketika dihdapkan pada permasalahan sederhana yang akhirnya hal ini berdampak dalam menghadapi persoalan pada pembelajaran matematika.

Selain peran guru sebagai motivator dalam kegiatan instruksional, pemilihan metode juga mendukung dalam kegiatan pembelajaran, karena bagaimanapun juga guru sudah seharusnya mampu membuat sebuah atmosfer belajar yang menyenangkan. Metode belajar yang berorientasi pada siswa juga diharapkan dapat menjadi inovasi dalam menciptakan suasana beajar yang menarik dan menenangkan, ada beberapa metode pembelajaran yang menyenangkan, diantaranta adalah; Problem Based Learning (PBL), Team Games Tournament (TGT), Jigsaw Model, dan Cooperative Learning.

Pembelajaran Matematika tentu tidak lepas dari beberapa implementasi teori psikologi konstruktivisme. Menurut (Akbarita et al., 2016) konstruktivisme adalah proses belajar yang terjadi berdasarkan apa pengalaman nyata yang langsung dirasakan oleh siswa, dalam hal ini guru bukanlah satu-satunya yang memberi pengalaman belajar.

Model instructional cooperative learning tipe CORE (Connecting, Organizing, Reflecting, Extending) dapat menjadi alternatif metode instruksional yang diharapkan senantiasa membangkitkan motivasi belajar kepada siswa dengan harapan siswa mudah dalam memahami pembahasan yang telah diajarkan oleh guru atau sebagai penunjang dalam kegiatan belajar matematika yang menyenangkan untuk mengkondisikan siswa agar lebih aktif. Dalam pembelajaran ini guru mengandalkan konsep lama yang telah dimiliki siswa untuk dikolaborasikan dengan konsep baru. Pembelajaran ini memiliki ciri menggabungkan, mengorganisasikan, menggali, dan mengembangkan konsep.

Anastasiadou (2008) mendefinisikan representasi sebagai semua konfigurasi atau aturan karakter, gambar, benda konkret, dan lain-lain yang dapat menggambarkan atau "mewakili" sesuatu objek lain. Sedangkan menurut (Hwang et al., 2007) representasi diftafsirkan berbeda tergantung dengan konteksnya. Ditinjau dari lingkup matematis menurut (Rahmadian et al., 2019) represetasi adalah kemampuan menjelaskan kembali berupa symbol-simbol matematis, baik berupa simbol, tabel, notasi, diagram, hingga persamaan kedalam bentuk lain.

Kartini (2009) mengklasifikasikan representasi eksternal pada dua jenis adalah representasi descriptive dan depictive. Maksud dari descriptive terdiri dari beberapa simbol yang memiliki rancangan secara acak yang dikoneksikan pada isi yang digambarkan simpel dengan tafsir dari suatu konvensi yang berupa tulisan. Sedangkan yang dimaksud dengan representasi depictive diantaranya adalah tanda yang bersifat ikonik yang dikorelasikan dengan konten yang dideklarasikan melalui fitur struktural yang umum secara kongkret atau pada sebuah level yang lebih abstrak, yaitu berupa gambaran visual.

Suryana (2012) menjelaskan, pada hakikatnya siswa dapat menyampaikan gagasan maupun ide matematikanya ke dalam tiga bentuk representasi yaitu:

1. Representasi visual dengan gambar, diagram, grafik atau tabel.

Pengaruh Model Instruksional| 182 
2. Representasi simbolik melalui pernyataan, ekspresi, atau notasi matematik, numerik atau dalam bentuk aljabar.

3. Representasi verbal atau teks tertulis.

Lebih lanjut Suarcita et al., (2020) mengatakan bahwa representasi siswa yang berbeda akan berpengaruh terhadap metode pembelajaran yang dipilih oleh guru, terlebih lagi pembelajaran yang menitik beratkan pada aspek kognitif multi representasi akan menjadi pelengkap.

Dalam penelitian yang dilakukan ini, penulis juga mencantumkan beberapa riset terdahulu yang memiliki relevansi pada riset yang dilakukan peneliti diantaranya pada sebuah riset yang berjudul "Model Pembelajaran CORE Berbantuan Marcomedia Flash 8 Terhadap Kemampuan Pemecahan Masalah Matematika Siswa SMP Negeri 15 Palembang" yang dilakukan oleh Ramadhan \& Fitriasari (2019) disebutkan ternyata Matematika adalah sebuah ilmu pengetahuan yang dalam pemecahannya memerlukan basic pengetahuan, skill, dan ilmu yang terintenalisasi dari akumulasi yang telah dipelajari sebelumnya.

Hal ini semakin dipertegas dengan hasil riset yang pernah diujicoba oleh Trisnowali \& Aswina (2019) dikatakan bahwa model pembelajaran Matematika berbasis CORE guru sudah selayaknya menjadi fasilitator dan aktif dalam kegiatan instruksional sehingga diharapkan guru mampu menstimulus arahan kepada siswanya yang membuat lebih antusias belajar dan berfikir lebih HOTS dalam memecahkan masalah matematika.

Berdasarkan paparan pendahuluan yang telah disebutkan sebelumnya, maka tujuan dari penelitian ini adalah.

1. Mengetahui peningkatan abilitas siswa dalam melakukan representasi matematis setelah mengalami kegiatan instruksional matematika dengan menggunakan model kooperatif tipe CORE.

2. Mengetahui perbedaan abilitas representasi matematis antara siswa yang mengalami kegiatan instruksional model CORE dengan siswa yang menerapkan kegiatan instruksional dengan pendekatan saintifik.

3. Mengetahui respons siswa terhadap pembelajaran dengan implementasi model kooperatif tipe CORE.

Model Kegiatan Instruksional Kooperatif tipe CORE (Connecting, Organizing, Reflecting, and Extending)

CORE yakni salah satu metode instruksional yang berbasis Student Centered Learning dengan model kooperatif learning diskusi yang mencoba merangsang siswa dalam rangka meningkatkan partisipasi dan supporting system dalam menguasai materi yang telah diajarkan guru dalam rangka mendapatkan hasil belajar yang maksimal. Hal ini didukung oleh Calfee (Hariyanto, 2017) yang menyatakan bahwa model pembelajaran CORE adalah kegiatan pembelajaran interaksi antar siswa yang memiliki implikasi pada aspek kognitif dan kemampuan siswa berpikir dalam melakukan refleksi, kemampuan reflektif siswa adalah suatu kegiatan berpikir ketika siswa mengonstruksi sendiri pengetahuan yang telah dipelajari dengan sebuah paradigma baru dan mencoba untuk senantiasa mengelola proses berpikirnya.

CORE sebagai salah satu diantara banyaknya metode pembelajaran yang berorientasi kepada siswa merupakan akronim, yaitu: 
1. Connecting (menghubungkan beberapa pengetahuan sebelumya dan pengetahuan yang baru diantara beberapa konsep yang sudah dipelajari),

2. Organizing (mengorganisasikan beberapa gagasan dan ide dalam rangka memudahkan dalam memahami materi),

3. Reflecting (menganalisis kembali, mendalami, dan mencari informasi yang telah didapat) dan,

4. Extending (mengembangkan, memperluas, menggunakan, dan menemukan hal baru).

\section{METODE}

Metode penelitian yang peneliti lakukan dalam mengembangkan riset ini adalah jenis Quasi Experimental Design tipe Nonequivalent Control Group Design. Penelitian dengan pendekatan ini, baik kelompok ujicoba dengan kelompok kontrol dibandingkan, meskipun kelompok tersebut ditetapkan tanpa acak. Dua kelompok yang telah ditentukan diberikan tes pendahuluan (pre-test), kemudian diberikan perlakuan, dan pada tahap akhir diberikan tes evaluasi (post-tes).

Dalam jurnal yeng berjudul "implementation of colt model (type structured problem solving) and its effect on problem solving ability for high school students" metode Quasi Experimental Design adalah metode yang cocok diterapkan pada kelompok-kelompok penerima maupun eksperimen tidak dipilih secara acak (Na, 2018). Adapun menurut Zakiyatun et al., (2017) metode Non equivalent Control Group Design adalah pemilihan sampel penelitian yang tidak secara acak melainkan dengan tujuan kesetaraan antara kelas control maupun kelas yang diberikan perlakuan.

Populasi yang penulis tentukan ketika melakukan penelitian ini adalah semua siswa kelas VIII SMPIT Al Ihsan Legenda Kota Bekasi. Adapun pengambilan instrumen sebagai sampel dilakukan secara purposive dengan pertimbangan tertentu, untuk mencari dua kelas yang memiliki kemampuan relatif sama. Beberapa pertimbangan yang dipilih dalam pengambilan sampel dalam penelitian ini adalah kemampuan representasi siswa antara kelas ujicoba dan kelas kontrol dalam tingkat kemampuan rata-rata kelas yang hampir sama atau homogen. Pengambilan sampel juga harus dilatarbelakangi oleh karakteristik, ciri, atau kondisi yang merupakan ciri-ciri pokok populasi.

Pendekatan metode penelitian yang diimplementasikan adalah sesuai dengan pendapat (Sugiyono, 2015) dalam sebuah gambaran sebagai berikut.

Keterangan.

$\mathrm{E} \quad=$ kelas eksperimen;

$\mathrm{K}=$ kelas kontrol;

$\mathrm{X}=$ pembelajaran matematika model CORE

O1 = tes awal (pretes);

$\mathrm{O} 2=$ tes akhir (postes).

HASIL

Berdasarkan pertimbangan dan tujuan penelitian antara dua popuilasi kelas 
berbeda yang dianggap memiliki tingkat rata-rata abilitas siswa dalam melakukan representasi yang relatif sama atau homogen antara kelas eksperimen dan kelas kontrol. Oleh karena itu, yang dijadikan sampel dalam penelitian ini adalah kelas VIII-C sebagai kelas ujicoba dan kelas VIII-B sebagai kelas kontrol. Kelas ujicoba diterapkan metode instruksional matematika dengan menggunakan model kooperatif tipe CORE adapun kelas kontrol menggunakan instruksional dengan pendekatan saintifik. Jenis pembahasan materi matematika yang dipelajari pada kedua kelas tersebut adalah sama yaitu mengenai Fungsi.

Hasil yang telah diperoleh dari riset ini berupa jenis kuantitatif yaitu hasil uji pendahuluan dan tes akhir dari kedua kelas dan data kualitatif yaitu berupa hasil respons siswa berupa angket. Berikut ini deskripsi nilai hasil pretes dan postes kelas ujicoba dan kelas kontrol yang tertera pada tabel yang peneliti uraikan berikut ini:

Tabel 1. Statistik Deskriptif Data Hasil Tes Pendahuluan

Eksperimen

\begin{tabular}{lcc} 
& Eksperimen & Kontrol \\
\hline \hline Jangkauan & 40 & 37 \\
Minimal & 27 & 27 \\
Maksimal & 5 & 5 \\
Rata-rata & 32 & 32 \\
Simpangan baku & 17,58 & 17,38 \\
Varians & 7,074 & 6,869 \\
\hline
\end{tabular}

Tabel 2. Statistik Deskriptif Data Hasil Tes Akhir

Eksperimen

\begin{tabular}{lcc}
\hline \hline N & 30 & 37 \\
Jangkauan & 29 & 57 \\
Minimal & 67 & 39 \\
Maksimal & 96 & 96 \\
Rata-rata & 78,77 & 68,49 \\
Simpangan baku & 7,213 & 13,123 \\
Varians & 52,025 & 172,201 \\
\hline
\end{tabular}

Kedua tabel 1 dan 2 di atas menampilkan sebuah informasi bahwa total sampel yang terdapat pada kelas uji coba dan kelas kontrol yaitu 40 dan 37 siswa. Rata-rata nilai pada tes pendahuluan kelas uji coba adalah 17,58 dan kelas control adalah 17,38. Sedangkan rata-rata tes evaluasi kelas uji coba 78,77 dan kelas kontrol adalah 68,49. Perolehan nilai terendah tes pendahuluan pada kelas ujicoba dan kelas kontrol sama yaitu sebesar 5 , begitu pun pada nilai yang paling besar tes pendahuluan pada kelas uji coba dan kelas kontrol yaitu sebesar 32. Namun nilai terendah tes evaluasi kelas uji coba sebesar 67 dan kelas kontrol sebesar 39, sedangkan nilai tertinggi tes evaluasi kelas uji coba dan kelas kontrol memiliki nilai yang sama yaitu sebesar 96. Jangkauan tes pendahuluan kelas uji coba dan kelas kontrol sama yaitu sebesar 27. Sedangkan jangkauan tes evaluasi kelas uji coba sebesar 29, dan kelas kontrol sebesar 57. Simpangan baku pretes kelas uji coba 7,074 dan kelas kontrol adalah 6,869, adapun varians pretes untuk kelas uji coba adalah 50,046 dan kelas kontrol adalah 47,186. Sementara itu simpangan baku postes kelas uji coba 7,213 dan kelas kontrol adalah 13,123 , sedangkan varians untuk kelas uji coba adalah 52,025 dan kelas kontrol adalah 172,201 .

185 | Akademika | Vol 10 | No. 1 | 2021 


\section{PEMBAHASAN}

\section{Peningkatan Kemampuan Representasi Matematis pada Siswa Dengan Metode Instruksional Menggunakan Kooperatif tipe CORE}

Dari analisis data menunjukan terdapat kenaikan abilitas representasi matematis siswa secara keseluruhan setelah dilaksanakannya kegiatan instruksional dengan menggunakan model kooperatif tipe CORE. Dalam kegiatan instruksional dengan menggunakan model CORE, siswa sudah mulai aktif bertanya dan menguraikan beberapa pertanyaan yang diberikan dalam bentuk instrumen tes yang diberikan oleh guru, siswa lebih berkonsentrasi dalam belajar dan memberikan kemudahan pada siswa dalam memahami mengenai materi yang diajarkan. Kondisi ini membuat proses kegiatan instruksional dapat berlangsung dengan sebagaimana mestinya dan sesuai dengan perencanaan, dengan demikian terciptalah sebuah kegiatan timbal balik pembelajaran yang sangat positif antara guru dengan siswa.

Dalam impelementasi kegiatan instruksional model kooperatif tipe CORE memberikan dampak yang positif terhadap abilitas representasi matematis siswa yang mengalami peningkatan yang nyata. Terlihat dari hasil rata-rata tes pendahuluan dan tes evaluasi menunjukan hasil yang signifikan pada kelas eksperimen. Rata-rata pretes pada kelas ujicoba sebesar 17,58 dan postes 78,77 sehingga terlihat bahwa rata-rata tes pendahuluan lebih kecil dibandingkan rata-rata tes evaluasi setelah menggunakan model CORE. Hal ini didukung dengan dilakukannya uji gain ternormalisasi untuk melihat peningkatan skor dari hasil tes pendahuluan dan tes akhir pada kelas eksperimen.

\section{Perbedaan Representasi Matematis Dengan Siswa yang Kegiatan Instruksional Model Kooperatif tipe CORE dan Kegiatan Instruksional yang Menggunakan Pendekatan Scientific}

Dari hasil keseluruhan tes pendahuluan didapatkan hasil pada rata-rata kelas ujicoba dengan nilai perolehan 17,58 dan nilai perolehan rerata kelas kontrol 17,38. Hal dapat diartikan bahwa tes pendahuluan yang dilakukan pada dua kelas sebelum diberi perlakuan dapat dikatakan sama atau homogen. Hal ini didukung dengan analisis data dengan menggunakan uji-t (Independent Sample t-Test) diperoleh ternyata tidak ditemukan signifikasi abilitas awal, yaitu abilitas siswa dalam merepresentasikan matematis antara kelas ujicoba dengan kelas kontrol.

Sedangkan tes evaluasi didapat hasil signifikansi hasil perbandingan kelas ujicoba dan kelas kontrol. Hasil tes evaluasi diperoleh bahwa rata-rata pada kelas ujicoba sebesar 78,77 dan rata-rata kelas kontrol 68,49. Hal ini didukung dengan analisis pada data yang kemudian dilanjutkan dengan uji-t (Independent Sample t-Test) yang ternyata terdapat sebuah signifikasi kemampuan akhir representasi matematis siswa pada kedua kelas yang diujicobakan (kelas eksperimen) dengan kelas kontrol.

Pada saat dilakukannya kegiatan instruksional matematika dengan menerapkan model kooperatif tipe CORE terlihat signifikansi dari hasil lapangan yang peneliti temukan pada kelas eksperimen, hampir semua kegiatan dalam kegiatan instruksional, siswa ikut berperan proaktif dalam melaksanakan kegiatan instruksional. Hal ini tentu saja memiliki relevansi dengan sebuah riset yang pernah dilakukan oleh Rokhaeni 
(2011), ternyata rata-rata kemampuan menghubungkan matematis siswa yang dalam kegiatan instruksionalnya mengimplementasikan pembelajaran kooperatif CORE dinilai lebih optimal dibandingkan dengan siswa yang pembelajarannya menggunakan model saintifik. Hal ini tentu saja karena pembelajaran CORE lebih mengedepankan bagaimana agar siswa belajar aktif melalui diskusi yakni adanya peran aktif siswa dalam kegiatan instruksionalnya secara partisipatif yang dapat meningkatkan hasil belajar siswa. Selain itu CORE juga merupakan suatu model yang melatih siswa untuk terlibat secara aktif melalui diskusi untuk mengaitkan, mengorganisasikan, menyimpulkan dan memperluas pengetahuan yang dimiliki, sesuai dengan pendapat Calfee (Hariyanto, 2017) yaitu, "model CORE merupakan model diskusi yang mempengaruhi perkembangan pengetahuan dan berpikir efektif siswa".

Sedangkan pembelajaran pada kelas kontrol, mayoritas siswa dinilai sangat minim dalam berperan aktif dalam pembeajaran dan hanya sebagian siswa saja yang terlihat aktif di kelas jika dibandingkan dengan kelas yang dilakukan ujicoba. Tentu saja hasil analisis ini diamati dari sikap sebagian siswa yang cendrung kurang antusias dan kurang kreatif dalam pembelajaran, dikarenakan tidak adanya keterlibatan siswa secara langsung dalam kegiatan instruksional yang sedang dilakukan. Dengan demikian, dinilai sebagian besar siswa yang belum paham materi pembelajaran dikarenakan kurangnya juga motivasi siswa untuk mengikuti pembelajaran.

\section{Respons Siswa terhadap Pembelajaran yang Menggunakan Model Kooperatif tipe CORE}

Gambaran mengenai respons siswa dalam kegiatan instruksional matematika dengan menggunakan model CORE dapat disimpulkan dari hasil penyebaran kuesioner yang diperoleh. Pembelajaran dengan menggunakan model kooperatif tipe CORE membuat mereka aktif dan kreatif dalam mempelajari matematika, hal ini mengcu pada hasil angket yang telah didapatkan. Selain itu, siswa pun lebih percaya diri dalam mempelajari matematika terlebih lagi antusiasme dalam mengerjakan soal matematika. Banyak siswa yang beranggapan bahwa setelah dilakukannya pembelajaran dengan menggunakan model CORE mereka merasa banyak pengetahuan yang mereka peroleh, dalam diskusi kelompok pun mereka menjadi lebih percaya diri untuk menyampaikan apa yang menjadi argumentasinya, baik kepada teman satu kelompok maupun teman satu kelas dan hampir seluruh siswa beranggapan bahwa dengan menggunakan model kooperatif tipe CORE sangat efektif, mereka merasa lebih mudah untuk memahami materi fungsi.

Menurut (Wati et al., 2018) model pembelajaran CORE adalah pembelajaran yang didesain untuk membangun keaktifan siswa agar lebih mudah membangun pengetahuan yang baru dalam paradigma mereka sendiri (Wati et al., 2018). Atau dengan kata lain model kegiatan instruksional ini adalah model kegiatan instruksional yang berorientasi pada siswa dengan harapan siswa mampu menganalisis dan memecahkan permasalahan dalam pembelajaran matematika.

Dalam proses pembelajaran hanya sebagian kecil siswa beranggapan bahwa dalam kegiatan instruksional menggunakan model kooperatif tipe CORE, guru tidak pernah memberikan bimbingan kepada mereka jika mereka mengalami kesulitan dalam proses instruksional, hal ini dilihat dari hasil angket yang diperoleh. Selain itu, sebagian 
kecil siswa beranggapan ternyata kegiatan instruksional dengan implementasi model kooperatif tipe CORE membuat mereka tegang dan konsentrasi belajar mereka terganggu jika berdiskusi dengan teman serta membuat pembelajaran tidak efektif, sehingga hanya sebagian kecil dari mereka beranggapan bahwa nilai matematika mereka menurun ketika mereka merasakan pengalaman dalam sebuah kelas yang pembelajarannya menggunakan model tipe CORE.

\section{KESIMPULAN}

Berdasarkan paparan dan beberapa data yang telah dianalisis pada pembahasan sebelumnya tentu dapat dituliskan beberapa poin yang dapat disimpulkan sebagai berikut: Kegiatan instruksional mata pelajaran matematika yang terimplementasi dengan model kooperatif tipe CORE dapat melejitkan kemampuan representasi matematis siswa pada pembahasan matematika sub tema fungsi. Adanya kenaikan kemampuan representasi matematis siswa dengan kegiatan instruksional menggunakan model kooperatif tipe CORE mengalami peningkatan dengan kategori tinggi.

Ada signifikansi abilitas siswa dalam melakukan representasi matematis jika membandingkan siswa yang dalam kegiatan instruksionalnya menggunakan model kooperatif tipe CORE pada pembelajaran matematika subtema fungsi dengan siswa yang metode pembelajarannya menggunakan pendekatan scientific pada pokok bahasan fungsi. Pembelajaran matematika menggunakan model CORE dinilai memiliki efektifitas yang baik jika dibandingkan dengan pembelajaran matematika yang menggunakan pendekatan scientific pada pokok bahasan fungsi.

Respons siswa pada akhir kegiatan instruksional yang diimplementasikan model CORE ternyata mayoritas siswa merasakan adanya manfaat ketika metode ini diterapkan dalam kegiatan instruksional mereka dan hanya sebagian kecil lainnya belum merasakan manfaat dengan diterapkannya model kooperatif tipe CORE dalam kegiatan instruksional matematika. Hal ini menunjukkan bahwa hanya sebagian kecil siswa yang masih menganggap pelajaran matematika adalah pelajaran yang sangat sulit dan menakutkan.

\section{DAFTAR PUSTAKA}

Akbarita, R., Sri, M., \& Santi Irawati. (2016). Interaksi Guru dan Siswa Kelas VII Untuk Membantu Memahami Konsep Transformasi. Jurnal Pembelajaran Matematika, III(1).

Anastasiadou, S. (2008). The Effects of Representational Systems on the Learning of Statistics Between Greek Primary School Students and Immigrants. University of Western Macedonia.

Hariyanto. (2017). Penerapan Model CORE dalam Pembelajaran Matematika untuk Meningkatkan Kemampuan Komunikasi Matematik Siswa. Jurnal Gammath, 2(1), 11-19. http://jurnal.unmuhjember.ac.id/index.php/JPM/article/view/575

Hwang, W. Y., Chen, N. S., Dung, J. J., \& Yang, Y. L. (2007). Multiple representation skills and creativity effects on mathematical problem solving using a multimedia 
whiteboard system. Educational Technology and Society, 10(2), 191-212.

Jaya Putra, H. E., Situmorang, R., \& Muslim, S. (2020). Development of a Printed Hypertcontent Module for Leadership Subjects At Fitrah Islamic World Academy Senior High Bogor. Akademika, 9(02), 1-15.

https://doi.org/10.34005/akademika.v9i02.1009

Kartini. (2009). Peranan Representasi dalam Pembelajaran Matematika. Seminar Nasional Matematika Dan Pendidikan Matematika UNY, 361-372.

M. Pd, K. (2016). Pengaruh Strategi Pembelajaran Berbasis Masalah Dan Model Pensekoran Terhadap Hasil Belajar Matematika Dengan Mengontrol Inteligensi Siswa. Akademika, 5(01), 139-152. https://doi.org/10.34005/akademika.v5i01.497

$\mathrm{Na}, \mathrm{S}$. (2018). Implementasi Model Colt (Tipe Structured Problem Solving) Dan Pengaruhnya Terhadap Kemampuan Pemecahan Masalah Bagi Siswa Sma. Akademika, 7(02), 46-65. https://doi.org/10.34005/akademika.v7i02.315

NCTM (National Council of Teachers of Mathematics). (2000). Principles and Standards for School Mathematics. NCTM.

Rahmadian, N., Mulyono, \& Isnarto. (2019). Kemampuan Representasi Matematis dalam Model Pembelajaran Somatic, Auditory, Visualization, Intellectually (SAVI). PRISMA, Prosiding Seminar Nasional Matematika, 2, 287-292.

https://journal.unnes.ac.id/sju/index.php/prisma/article/view/28940

Ramadhan, A. F., \& Fitriasari, P. (2019). Model Pembelajaran Core (Connecting , Organizing, Reflecting, and Extending) Berbantuan Macromedia Flash 8 Terhadap Kemampuan Pemecahan Masalah Matematika Siswa Smp Negeri 15 Palembang. Prosiding Seminar Nasional Pendidikan Program Pascasarjana Universitas PGRI Palembang 12 Januari 2019, 87-94.

Rose Mary, Z., Bradford, F., Evan, M., Glendon, B., Ryan, F., \& Gleason, B. (2018). Facilitator's guidebook for use of mathematics situations in professional learning. Information Age Publishing.

Suarcita, G. P., Astawa, I. W. P., \& Suarsana, I. M. (2020). Pengembangan Bahan Ajar Digital Interaktif Dengan Pendekatan Multi Representasi Pada Materi Bilangan Bulat Untuk Siswa Smplb Tunarungu Kelas Vii. Akademika, 9(01), 69-84. https://doi.org/10.34005/akademika.v9i01.731

Sugiyono. (2015). Metode Penelitian Pendidikan. Alfabeta,CV.

Suryana, A. (2012). Kemampuan berpikir matematis tingkat lanjut (Advanced mathematical thinking) dalam mata kuliah statistika matematika 1. Seminar Nasional Matematika Dan Pendidikan Matematika FMIPA UNY, November, 37-48.

Trisnowali, A., \& Aswina, A. (2019). Pengaruh Model Pembelajaran Core (Connecting, Organizing, Reflecting and Extending) Terhadap Hasil Belajar Siswa Kelas X. DIDAKTIKA : Jurnal Kependidikan, 13(1), 43-55. https://doi.org/10.30863/didaktika.v13i1.315

Wati, K., Hidayati, Y., Wulandari, A., \& Ahied, M. (2018). Pengaruh Model Pembelajaran Core ( Connecting, Organizing, Reflecting, Extending ) Terhadap. Journal of Natural Science Education Reseach, 1, 517-525. https://www.google.com/url?sa=t\&rct=j\&q=\&esrc=s\&source=web\&cd=1\&cad=rja\&u act=8\&ved=0ahUKEwjb_peAzdnZAhXLGZQKHe1IAD4QFggxMAA\&url=http\%3A\% 2F\%2Fsesiomadika.890m.com\%2FProsiding\%2F75TiaraAdieAryati- 
SESIOMADIKA-2017.pdf\&usg=AOvVaw1gtIn0tYPbAGPp_xlfyfLG

Wibisono, H. A., Situmorang, R., \& Solihatin, E. (2020). Pengembangan Video Animasi

Tutorial Ujian Tanda Kecakapan Khusus Pramuka Sekolah Dasar. Perspektif IImu

Pendidikan, 34(2), 125-136. https://doi.org/10.21009/pip.342.7

Zakiyatun, C., Cawang, C., \& Kurniawan, R. A. (2017). Pengaruh Media Peta Konsep

Dalam Model Pembelajaran Kooperatif Tipe Numbered Heads Together (Nht)

Terhadap Hasil Belajar Dan Daya Ingat Siswa Pada Materi Hidrolisis Garam Kelas

Xi Mipa Sma Negeri 7 Pontianak. AR-RAZI Jurnal Ilmiah, 5(2).

https://doi.org/10.29406/arz.v5i2.629 